\title{
降伏線理論に基づく $\mathrm{H}$ 形鋼ウェブ局部降伏の耐力評価式 STRENGTH FORMULA OF LOCAL WEB YIELDING OF WIDE-FLANGE STEEL BASED ON YIELD LINE THEORY
}

田川＼cjkstart浩*, 渡辺 貴 仁**, シベル グレル***

Hiroshi TAGAWA, Takahito WATANABE and Sibel GUREL

\begin{abstract}
In wide-flange steel shapes, concentrated flange force possibly causes the local failure originated from local web yielding, local flange bending and so on. This paper presents new formulae of local web yielding strength. The yield line theory is applied to obtain the strength considering the collapse mechanism where the yield lines form in the flange and the yield fields, in the web and flange. The proposed formulae include the sizes of the flange width and thickness which are not considered in the formula generally used in practice. The test results of the plate-to-wideflange steel connections show good agreement with the results of strength estimation. The measured residual flange deformation confirms the validity of the collapse mechanism considered.
\end{abstract}

Keywords : connection, wide-flange steel, yield line theory, local web yielding, strength, loading test 接合部, $\mathrm{H}$ 形鋼, 降伏線理論, ウェブ局部降伏, 耐力, 載荷実験

\section{1. 序}

$\mathrm{H}$ 形鋼がフランジに垂直に, ウェブに関して対称に集中荷重を受け ると, ウェブの局部降伏あるいはフランジの局部曲げ等が原因で局部 破壊に至る場合がある. H 形鋼の局部破壊が問題となるケースは幾つ かある. 例えばH形鋼の柱梁接合部において, 梁フランジからの集中 荷重により柱に局部破壊が生じると判断される場合には, 水平スチフ ナにより補剛する必要がある. $\mathrm{H}$ 形鋼の局部破壊に対する耐力評価に は，一般に設計指針等(1)に示されている耐力評価式が用いられる.

$\mathrm{H}$ 形鋼の局部破壊を引き起こす原因の 1 つであるウェブの局部降伏 に対する耐力評価式は, 図 1 に示すような局部降伏モデルAに基づい ている. 即ち，梁フランジ等を模した鋼板からの荷重 $P$ が，定められ た勾配で拡散しウェブに伝達されるものとして, ウェブフィレット先 端部の応力を検定する形式となっている. AISCの「LRFD設計基準」2? では, Graham ら5)による実験結果に基づき降伏範囲を $L=5 h+t_{b}$ と仮定 し，次のウェブ局部降伏耐力評価式を示している.

$$
P_{W}^{A 5}=\left(5 h+t_{b}\right) t_{w} \sigma_{w y}
$$

ここに, $t_{b}$ : 鋼板の厚さ, $t_{w}$ : ウェブの厚さ, $h$ : 柱フランジ外端よりウエ ブフィレット先端までの距離, $\sigma_{n y}$ : ウェブの降伏強さ. 斎藤6), 金谷7) の実験によってもこの妥当性が確認されており, 文献3), 4)にも式(1)と
同様の式が示されている. 一方文献 1)には, 降伏範囲を $L=2 h+t_{h}$ と仮 定した次の耐力評価式が示されている.

$$
P_{W}^{A 2}=\left(2 h+t_{b}\right) t_{n} \sigma_{n y}
$$

なお，式(1)と式(2)に対しては一般に異なる安全率が与えられる.

フランジに集中荷重を受けるH形鋼において, ウェブの局部降伏が 原因で局部破壊が生じる場合, ウェブだけでなくフランジにも塑性変 形が生じる. ところが, 式(1)あるいは式(2)で表される耐力評価式には フランジの幅および厚さは含まれていない，このことは, 規格化され ているような標準的な圧延H形鋼に対してはこれらの評価式が適用で きるものの，標準的ではないH形鋼では評価精度が低下する可能性が あることを示唆している. また, 式(1)と式(2)から得られる耐力評価値 には大きな差があるが, いずれを考虑するかは設計者により異なると いう状況が生じている.

本研究の目的は, $\mathrm{H}$ 形鋼ウェブの局部降伏に対し, フランジの幅お よび厚さを考慮した精度の高い耐力評価式を導出することである. 導 出には降伏線理論を適用する，降伏線理論は，鋼板やコンクリートス ラブ等が面外荷重を受ける部分の塑性崩罗荷重を導く際に有効な解析

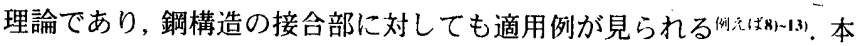
論文では，2 種類の崩壊機構を想定し耐力評価式を導出する.さらに,

\footnotetext{
本論文の一部は既に文献15), 16)に発表済みである。 名古屋大学大学院環境学研究科都市環境学専攻 助教授・博士 (工学)

** 名古屋大学工学部社会環境工学科 学部生

*** 名古屋大学大学院工学研究科土木工学専攻 大学院生·工修
}

Assoc. Prof., Division of Environmental Engineering and Architecture, Graduate School of Environmental Studies, Nagoya University, Dr. Eng. Student, Department of Civil Engineering and Architecture, Faculty of Engineering, Nagoya University

Graduate Student, Department of Civil Engineering, Graduate School of Engineering, Nagoya University, M. Eng. 


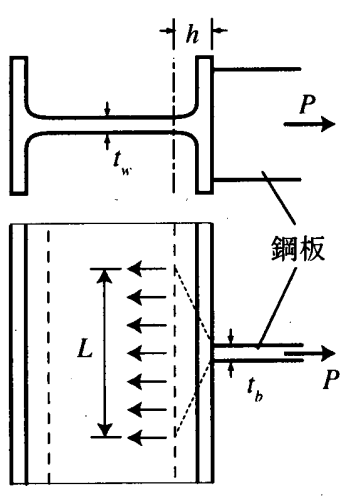

図 1 局部降伏モデル A

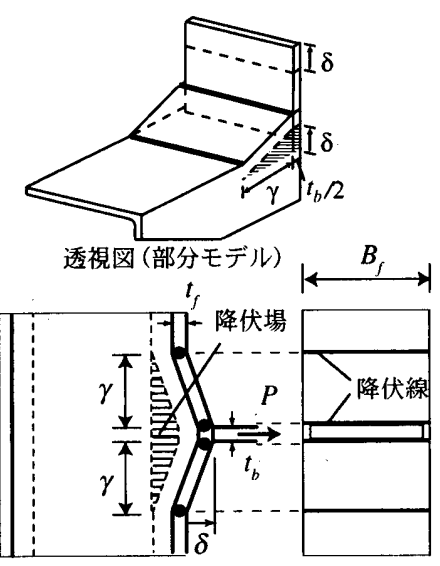

図 2 崩壊機構 B
接合部試験体を用いた引張および圧縮実験を行い，評価式の精度およ び想定した崩壊機構の妥当性を検証する.

\section{2. 降伏線理論による耐力評価式の導出}

本論文では図 1 に示した一般に用いられる局部降伏モデルAに対し て, 図 2 に示す崩壊機構 B および図 3 に示す崩壊機構 $\mathrm{C}$ を考える.い ずれの図も引張載荷時を想定しているが, 圧縮載荷時の崩壊機構も同 様に考えられる.

\section{1 崩壊機構 B に対する耐力評価式}

崩壊機構 $\mathrm{B}$ を示す図 2 において, $B_{f}$ : フランジ幅, $t_{f}$ : フランジの厚 さを表す. 降伏線を太線で, 降伏場を網掛けで表す. 同図上側にはウェ ブの中央面と鋼板の中央面で分割した部分モデルの透視図を示す，崩 壊機構 $\mathrm{B}$ は図 1 の局部降伏モデル $\mathrm{A}$ と類似しているが, 降伏モデル A ではウェブの降伏範囲 $L$ が指定されるのに対し, 崩壊機構 Bではウェ ブが降伏する範囲を $2 \gamma+t_{b}$ のように変数 $\gamma$ により表しておき，その值 を降伏線理論に基づいて算定する点が異なる.崩壊機構Bは文献 14)に も見られる.

図 2 に示すように鋼板に仮想変位 $\boldsymbol{\delta}$ を与えたとき，降伏線の回転角 は $\delta / \gamma$ となる. 降伏線における単位長さあたりの全塑性モーメントを $M_{p}$ で表すと, 降伏線 1 本分の内力仕事 $E_{Y L}^{i n}$ は次式となる.

$$
E_{Y L}^{i n}=M_{p} B_{f} \frac{\delta}{\gamma}
$$

降伏場の内力仕事 $E_{Y F}^{i n}$ は, 次式のように得られる.

$$
E_{Y F}^{i n}=\left(\gamma+t_{b}\right) t_{w} \sigma_{w y} \delta
$$

式(3)および(4)より内部仮想仕事の合計 $E_{B}^{i n}$ は次式のように得られる.

$$
E_{B}^{i n}=4 E_{Y L}^{i n}+E_{Y r}^{i n}
$$

一方, 鋼板に作用する荷重 $P$ による外力仕事 $E_{B}^{e x}$ は次式となる.

$$
E_{B}^{e x}=P \delta
$$

仮想仕事の原理から $E_{B}^{i n}=E_{B}^{e x}$ が成立する. 以上より, フランジの降伏 強さを $\sigma_{f y}$ とし, $M_{p}=t_{f}^{2} \sigma_{f y} / 4$ とすると, 崩壊荷重の上界値 $\hat{P}_{w}^{B}$ は次式の ように得られる.

$$
\hat{P}_{w}^{B}=\left\{\frac{B_{f} t_{f}^{2} \sigma_{f y}}{\gamma}+t_{w} \gamma \sigma_{w y}\right\}+t_{b} t_{w} \sigma_{w y}
$$

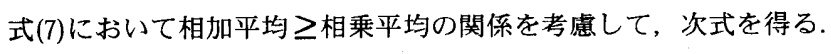

$$
\hat{P}_{W}^{B} \geq 2 t_{f} \sqrt{B_{f} t_{w} \sigma_{f y} \sigma_{w y}}+t_{b} t_{w} \sigma_{w y}=P_{W}^{B}
$$

等号は, 次の場合に成立する

$$
\gamma=t_{f} \sqrt{\frac{B_{f} \sigma_{f y}}{t_{w} \sigma_{u y}}}
$$

なお, 式(8)に示すように $\hat{P}_{W}^{B}$ の最小値を $P_{w}^{B}$ で表す. $P_{w^{\prime}}^{B}$ が崩壊機構 $\mathrm{B} に$ 対する耐力評価式である. ウェブとフランジの降伏強さが $\sigma_{y}$ で等しい 場合, 即ち $\sigma_{y}=\sigma_{w y}=\sigma_{f y}$ のとき, 式(8), (9)は次のように簡単化できる.

$$
P_{W}^{B}=2 t_{f} \sigma_{y} \sqrt{B_{f} t_{w}}+t_{b} t_{w} \sigma_{y}, \quad \gamma=t_{f} \sqrt{\frac{B_{f}}{t_{w}}}
$$

式(10a)と同様の式は文献 14)にも見られる.

\section{2 崩壊機構 Cに対する耐力評価式 \\ 2.2.1 崩壊機構 C}

崩壊機構 $\mathrm{C}$ を図 3 に示す. 図中, $r$ : フィレット半径, $m\left(=t_{w}+2 r\right)$ : フランジにおけるフィレット先端間の距離, $I:$ フィレット先端からフ ランジ端までの距離を表す．溶接の余盛を考慮して，鋼板から荷重が フランジに作用する範囲を $n$ で表し鋼板の厚さ $t_{n}$ とは区別する．ただ し，余盛が無視できる場合は $n=t_{b}$ とする（図 1 および図 2 では $n=t_{b}$ と した). 線分 BE と線分 AD の長さを変数 $\alpha$ および $\beta$ で表す. 崩壊機構 Cでは，ウェブに生じる降伏場 $\mathrm{a}$ に加えて，フランジにも降伏場 $\mathrm{b} か ゙$ 生 じる. 図 4 には，図3右図の左下部分を拡大した崩壊機構の詳細を示 す. 同(a)図はウェブの中央面と鋼板の中央面で分割した部分モデルの 透視図である. 同(b)図には降伏線理論を適用する際に用いる変数など を示す. 点 $M$ および点 $N$ はそれぞれ線分 $A B$ と線分 $D E$ の中点である. 点 $\mathrm{P}$ は直線 $\mathrm{DE}$ 上にあり, 直線 $\mathrm{PM}$ と直線 $\mathrm{DE}$ が直交するような点であ る. 線分 PMの長さを $x$, 線分 $\mathrm{DE}$ の長さを $y$ で表す.

崩壊機構 $\mathrm{B}$ とCに共通する点は, 荷重を与える鋼板に降伏場が生じ ないことである.この場合, 図4(a)から分かるように線分 $\mathrm{AB}$ は元のフ ランジ面と平行を保つ. 他方, 線分 $\mathrm{AB}$ がフランジ面と平行ではなく 鋼板にも降伏場が生じる崩壊機構 ${ }^{55}$ は, フランジの局部曲げによる局 部破壊形式に分類されるものと考えて, 本論文では対象としない.

\subsection{2 仮定の導入}

崩壊機構 Cに対し降伏線理論を適用する際に, 次に示す 2 つ仮定 を導入する。

仮定 1: 降伏場 $\mathrm{b}$ における内力仕事を無視する.

仮定 2: 降伏線 $\mathrm{AB}$ および降伏線 DEの回転角は一定とし, それぞ

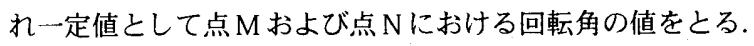
仮定 1 は, $\alpha \gg \delta$ かつ $\beta \gg \delta$ のき妥当と考えられる. 仮定 2 は次の 考えに基づいて導入する. 降伏線 $\mathrm{AB}$ の回転角は点 $\mathrm{A}$ から Bに向かつ て，降伏線 DEの回転角は点 DからEに向かって，それぞれ連続的に 增大していくものであり一定ではないが, 平均的な中点における回転 角を一定値として用いた場合には大きな誤差は生じないと考えられる. また, 仮定 2 を導入することにより, 耐力評価式を陽に導出すること が可能となる.

なお，仮定の妥当性について検討した結果を付録に示す.

\subsection{3 耐力評価式}

図 3 および図 4 に示すように鋼板に仮想変位 $\delta$ を与えたとき, 点 $M$ における降伏線の回転角は $2 \delta /(\alpha+\beta)$, 点 $N$ における降伏線の回転角 は $\delta / x$, 降伏線 $\mathrm{BC}$ の回転角は $\delta / \alpha$ となる. フランジ上の降伏線におけ る単位長さあたりの全塑性モーメントを $M_{p}$ で表すと, 降伏線 $\mathrm{AB}, \mathrm{DE}$ 


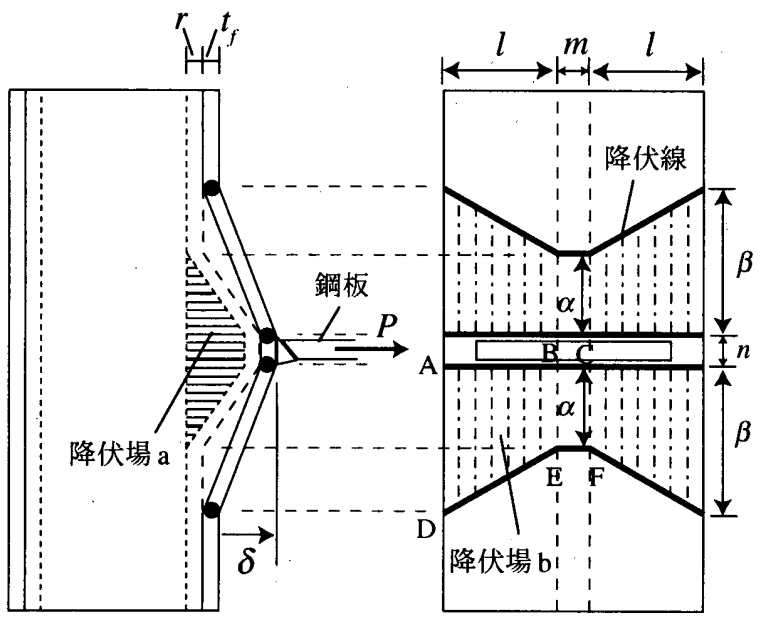

図 3 崩壊機構 C

および $\mathrm{BC}$ における内力仕事 $\left(E_{A B}^{i n}, E_{D E}^{i n}\right.$ おび $\left.E_{B C}^{i n}\right)$ は, それぞれ次 式のように得られる.

$$
\begin{aligned}
& E_{A B}^{i n}=M_{p} \frac{2 l \delta}{\alpha+\beta}, E_{D E}^{i n}=M_{p} \frac{y \delta}{x}, E_{B C}^{i n}=M_{p} \frac{m \delta}{\alpha} \\
& \text { ただし, } \quad x=\frac{l}{y} \cdot \frac{\alpha+\beta}{2}, y=\sqrt{l^{2}+(\beta-\alpha)^{2}}
\end{aligned}
$$

降伏場 $\mathrm{a}$ の内力仕事 $E_{\mathrm{a}}^{\text {in }}$ は, 次式のように得られる.

$$
E_{\mathrm{a}}^{i n}=(\alpha+n) t_{w} \sigma_{v y} \delta
$$

式(11)〜(13)より内部仮想仕事の合計 $E_{C}^{i n}$ は次式のように得られる.

$$
E_{C}^{i n}=4 E_{A B}^{i n}+4 E_{D E}^{i n}+4 E_{B C}^{i n}+E_{\mathrm{a}}^{i n}
$$

鋼板に作用する荷重 $P$ による外力仕事 $E_{C}^{e x}$ は次式で表される.

$$
E_{C}^{e x}=P \delta
$$

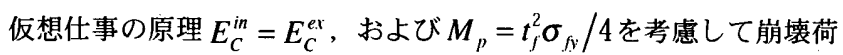
重の上界值 $\hat{P}_{W}^{C}$ が次式のように得られる.

$$
\hat{P}_{W}^{c}=t_{f}^{2} \sigma_{f y}\left\{\frac{4 l}{\alpha+\beta}+\frac{2}{l} \cdot \frac{(\beta-\alpha)^{2}}{\alpha+\beta}+\frac{m}{\alpha}\right\}+(\alpha+n) t_{w} \sigma_{w y}
$$

以下，ウェブとフランジの降伏強さが $\sigma_{v}$ で等しい場合を考える. ここ で, $\beta=\xi \alpha$ とおき式(16)に代入し, 整理すると次式を得る.

$$
\hat{P}_{w}^{C}=t_{f}^{2} \sigma_{y}\left\{\frac{4 l}{\xi+1}+m\right\} \frac{1}{\alpha}+\sigma_{y}\left\{\frac{2 t_{f}^{2}}{l} \cdot \frac{(\xi-1)^{2}}{\xi+1}+t_{w}\right\} \alpha+n t_{w} \sigma_{y}
$$

式(17)において, 相加平均 $\geq$ 相乗平均の関係を考虑すると次式を得る.

$$
\hat{P}_{W}^{C} \geq 2 t_{f} \sigma_{y} \sqrt{\left\{\frac{4 l}{\xi+1}+m\right\}\left\{\frac{2 t_{f}^{2}}{l} \cdot \frac{(\xi-1)^{2}}{\xi+1}+t_{w^{\prime}}\right\}}+n t_{w} \sigma_{y} \equiv P_{W}^{C}
$$

等号は, 次の場合に成立する

$$
\alpha=t_{f} \sqrt{\left\{\frac{4 l}{\xi+1}+m\right\} /\left\{\frac{2 t_{f}^{2}}{l} \cdot \frac{(\xi-1)^{2}}{\xi+1}+t_{w^{\prime}}\right\}}
$$

なお，式(18)に示すように $\hat{P}_{W}^{C}$ の最小値を $P_{W}^{C}$ で表す.

以上より, 耐力評価式は $P_{W}^{C}$ として得られたが, まだ変数 $\xi$ が含まれ

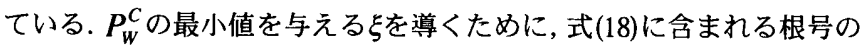

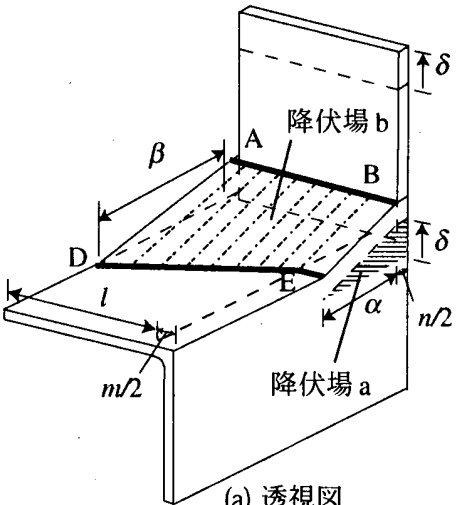

(a) 透視図

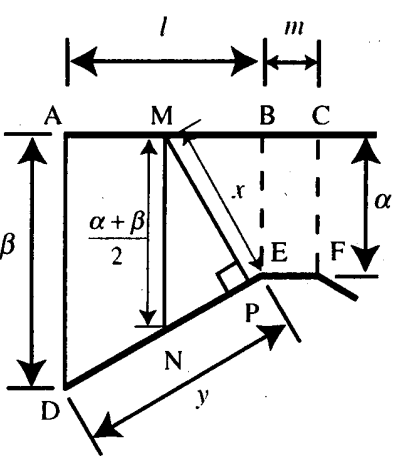

(b) 変数の定義
図 4 崩壊機構 $\mathrm{C}$ の詳細（部分モデル）

中を次式のように関数 $f(\xi)$ で表し, $f(\xi)$ の最小值を与える $\xi を$ 導く.

$$
\left.f(\xi)=\left\{\frac{4 l}{\xi+1}+m\right\} \frac{2 t_{f}^{2}}{l} \cdot \frac{(\xi-1)^{2}}{\xi+1}+t_{w}\right\}
$$

$f(\xi)$ をで微分すると次式を得る.

$$
\frac{\partial f(\xi)}{\partial \xi}=\frac{2\left\{16 t_{f}^{2}(\xi-1)+\frac{m t_{f}^{2}}{l}(\xi-1)(\xi+1)(\xi+3)-2 l t_{w}(\xi+1)\right\}}{(\xi+1)^{3}}
$$

$\partial f(\xi) / \partial \xi=0$ となるのは, 次式が成り立つときである.

$$
16 t_{f}^{2}(\xi-1)+\frac{m t_{f}^{2}}{l}(\xi-1)(\xi+1)(\xi+3)-2 l t_{n}(\xi+1)=0
$$

乡について整理すると次式を得る.

$$
A \xi^{3}+B \xi^{2}+C \xi+D=0
$$

ただし

$A=\frac{m t_{f}^{2}}{l}, B=\frac{3 m t_{f}^{2}}{l}, C=16 t_{f}^{2}-2 l t_{w}-\frac{m t_{f}^{2}}{l}, D=-16 t_{f}^{2}-2 l t_{w}-\frac{3 m t_{f}^{2}}{l}$ 式(23)の実数解は, 3 次方程式の解の公式 (カルダノの公式)を用いて, 次のように得られる.

$$
\xi=\frac{-B+\sqrt[3]{\eta_{1}}+\sqrt[3]{\eta_{2}}}{3 A}
$$

ここで, $\eta_{1}$ および $\eta_{2}$ は次の 2 次方程式の解である.

$$
\eta^{2}-E \eta+F^{3}=0
$$

ただし $E=9 A B C-2 B^{3}-27 A^{2} D, F=B^{2}-3 A C$

以上をまとめると, 耐力評価值 $P_{\mathrm{w}^{\prime}}^{C}$ は, 式(24)から $\xi$ 求め, これを 式(18)に代入することにより得られる. また， $\xi$ を式(19)に代入して得 られる $\alpha$ および $\beta(=\xi \alpha)$ から，降伏線が現れる位置を予想できる.

\section{3. 実験による耐力評価精度の検証}

\section{1 試験体および載荷・計測方法}

試験体は, 図 5 に示すように無補剛 $\mathrm{H}$ 形鋼柱梁接合部における引張 側および圧縮側梁フランジ部をモデル化したものである. 引張試験体 は，同(a)図に示すように 2 枚の鋼板を, ウェブに関して対称かつフラ ンジに垂直になるように完全溶込み溶接（裹はつり形式）によりフラ ンジ中央部に取り付ける. 万能試験機によりこれらの鋼板を揌み引張 
荷重 $P$ を漸增する．載荷はフランジの面外変形が明瞭となった時点で 終了し，最終破壊に達するまでは載荷しない，図中に示すようにフラ ンジから $100 \mathrm{~mm}$ 離れた鋼板上の 2 点間の変位 $\Delta$ を測定する. 一方, 圧 縮試験体は，図 5(b)に示すように一方のフランジに長さ $30 \mathrm{~mm}$ の鋼板 を溶接により取り付ける. 鋼板の無いフランジ面を下にして万能試験 機の圧板上に配置し，上方からもう1つの圧板（載荷板）により鋼板 端部に圧縮荷重を与える．圧板間の変位 $\Delta$ を測定する，全ての試験体 に対し，ウェブの降伏範囲を調べるための歪みゲージを図 5(c)に示す 位置に，鋼板の歪み分布を調べるための歪みゲージを図 7 左に示す位 置にそれぞれ添付する.

4 体の引張試験体および 1 体の圧縮試験体の諸元を表 1 に示す． H 形鋼の長さは局部破壊の影響が及ぶ範囲が含まれるようにいずれも $400 \mathrm{~mm}$ とした. 鋼種は全て SN400B であり, JIS Z2201の 1B 号試験片 による材料試験結果を表 2 に示す. 表 1 右側には, 各試験体のウェブ 局部降伏の耐力評価值 : $P_{W}^{A 5}$ (式(1)), $P_{W}^{A 2}$ (式(2)), $P_{w}^{B}$ (式(8)), $P_{W}^{C}$ (式 (18)）および鋼板の降伏耐力評価值 $: P_{b}$ を示す. $P_{w}^{A 5}, P_{w}^{A 2}$ および $P_{W}^{B}$ を 導出する際にも $P_{W}^{C}$ と同様に溶接の余盛を考慮した. 表中 $P_{W}^{C}$ の欄には, 式(24)より得られる 構はいずれも引張載荷時を想定しているが, 圧縮載荷時の崩壊機構も 同様に考えられ，引張および圧縮載荷時で耐力評価值は等しくなる. よって, 引張試験体 ST3 と圧縮試験体 SCは同じ耐力評価値となってい る. $\mathrm{H}$ 形鋼の局部破壊が生じる前に鋼板が破壊することを避けるため, 鋼板の降伏耐力評価値 $P_{b}$ が他よりも十分大きくなるよう鋼板のサイズ を決定した。

\section{2 荷重 変形関係曲線}

図 6 に荷重〜変形関係を示す. 図中に耐力評価值のレベルを示す. いずれのケースも $P_{w}^{A 2}$ が低く評価している. $P_{w}^{A 5}, P_{w}^{B}, P_{w}^{C}$ は比較的近接 しているが,その中では $P_{W}^{C}$ が最も低く評価している. $P_{W}^{C}$ の值は, $P_{W}^{B} に$ 対して $5 \% \sim 10 \%$ 小さい. 降伏線理論は任意の崩壊機構を仮定し, 対 応する崩壊荷重を最小化するもので上界定理に属する. $P_{w}^{B}$ と $P_{w}^{C}$ はいず

れも上界定理に基づいて得られたものであり,值の小さい $P_{w^{\prime}}^{C}$ の方が真 の崩壊荷重に近いと考える. 釣合条件と塑性条件を考慮する必要があ る下界定理を本問題に適用するのは困難である. 荷重〜変形関係曲線 から， $P_{W}^{C}$ により十分な精度で耐力評価ができていることが分かる. $P_{w^{\prime \prime}}^{A 5}$ については, 試験体ST1のケースで高めであるが, その他は $P_{w}^{R} に$ 近い 值となっている.なお, 本論文で用いた試験体は比較的小型であり，評 価精度の一般性の確認は今後の課題である.

試験体ST4では, 評価値 $P_{W}^{C}$ に達する以前に $150 \mathrm{kN}$ 付近から剛性の低 下が見られる. 図 7 に各試験体について荷重が各々の $P_{W}^{C}$ の値に達した 時点における鋼板の歪み分布を示す. 中央部の歪みが大きくなってい るが，ST4以外は概ね弾性限界 $(\varepsilon)$ 内である. ST4については，中央部 付近の歪みが塑性域に入っている。これが， $P_{w}^{C} に$ 達する以前に剛性が 低下した原因であると考えられる，ST4のようなケースでは，フラン ジの局部曲げによる局部破壊耐力の検討も重要になる.

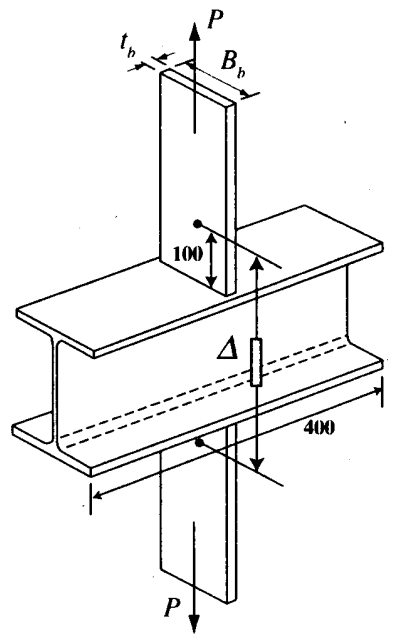

(a) 引張試験体

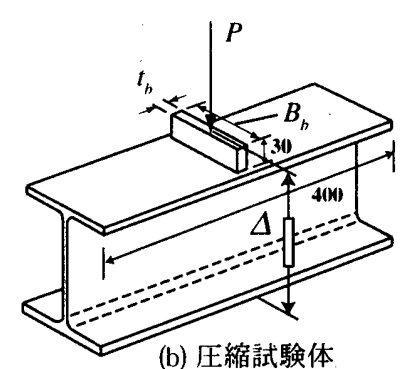

(b) 圧縮試験体

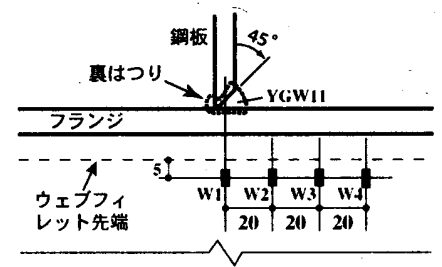

(c) 溶接部詳細および歪み計測位置

図 5 試験体形状（単位：mm）

表 2 材料特性

\begin{tabular}{|c|c|c|c|c|c|c|c|c|}
\hline 試験体 & H形鋼 & $\boldsymbol{B}_{b}(\mathrm{~mm})$ & $\boldsymbol{t}_{b}(\mathrm{~mm})$ & $\boldsymbol{P}_{w}{ }^{{ }^{5}}(\mathrm{kN})$ & $\boldsymbol{P}_{w}{ }^{2}(\mathrm{kN})$ & $\boldsymbol{P}_{w}{ }^{B}(\mathrm{kN})$ & $\boldsymbol{P}_{w}{ }^{c}(\mathrm{kN})|\xi|$ & $\boldsymbol{P}_{b}(\mathrm{kN})$ \\
\hline ST1 (引張) & $100 \times 100 \times 6 \times 8$ & 80 & 12 & 172 & 87.5 & 146 & $139|2.1|$ & 298 \\
\hline ST2 (引張) & $125 \times 125 \times 6.5 \times 9$ & 100 & 12 & 180 & 91.3 & 177 & $159|2.4|$ & 372 \\
\hline ST3 (引張) & $125 \times 125 \times 6.5 \times 9$ & 100 & 9 & 175 & 86.0 & 173 & $154|2.4|$ & 274 \\
\hline ST4 (引張) & $150 \times 150 \times 7 \times 10$ & 100 & 12 & 237 & 119 & 243 & $224|2.7|$ & 372 \\
\hline SC (圧縮) & $125 \times 125 \times 6.5 \times 9$ & 100 & 9 & 175 & 86.0 & 173 & $154|2.4|$ & 274 \\
\hline
\end{tabular}

\begin{tabular}{|c|c|c|c|}
\hline 材料 & $\begin{array}{c}\text { 降伏強さ } \\
\left(\mathrm{N} / \mathrm{mm}^{2}\right)\end{array}$ & $\begin{array}{c}\text { 引張強さ } \\
\left(\mathrm{N} / \mathrm{mm}^{2}\right)\end{array}$ & $\begin{array}{c}\text { 伸び率 } \\
(\%)\end{array}$ \\
\hline $\mathrm{H}-100 \times 100$ & 292 & 444 & 27.0 \\
\hline $\mathrm{H}-125 \times 125$ & 270 & 437 & 28.0 \\
\hline $\mathrm{H}-150 \times 150$ & 314 & 476 & 29.5 \\
\hline $9 \mathrm{~mm}$ 鋼板 & 305 & 446 & 29.5 \\
\hline $12 \mathrm{~mm}$ 鋼板 & 310 & 451 & 29.0 \\
\hline
\end{tabular}

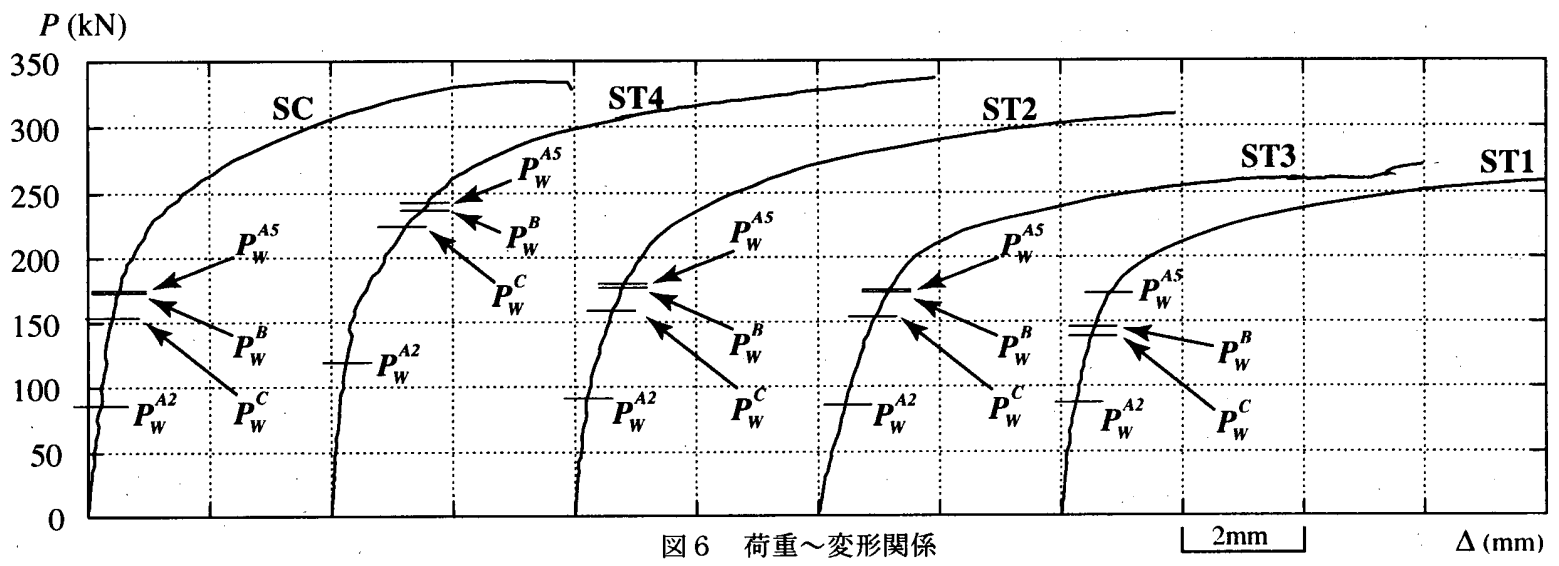




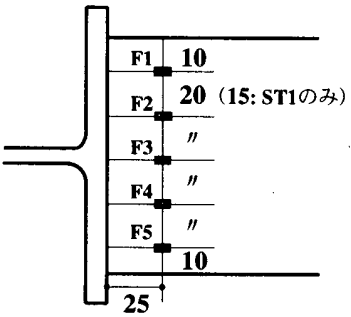

図 7 荷重 $P_{w}^{C}$ 作用時における鋼板の歪み分布

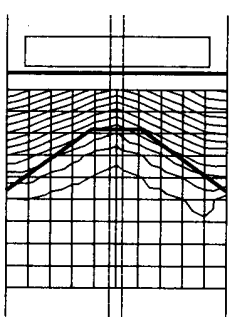

(a) 試験体 ST1
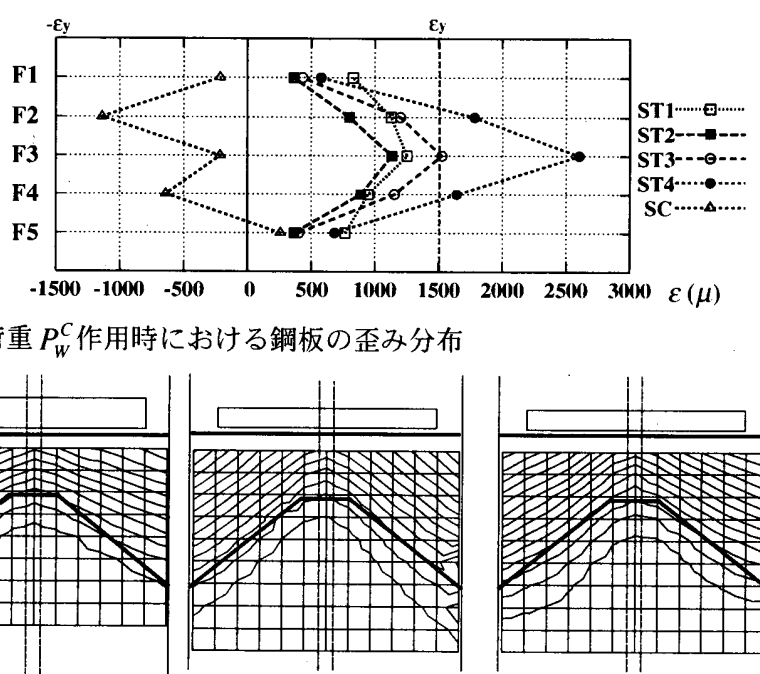

(c) 試験体 ST3

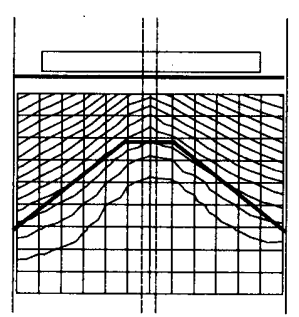

(d) 試験体 SC

図 8 実験後のフランジ面外残留変形の等高線（細実線）および予想降伏線（太実線）
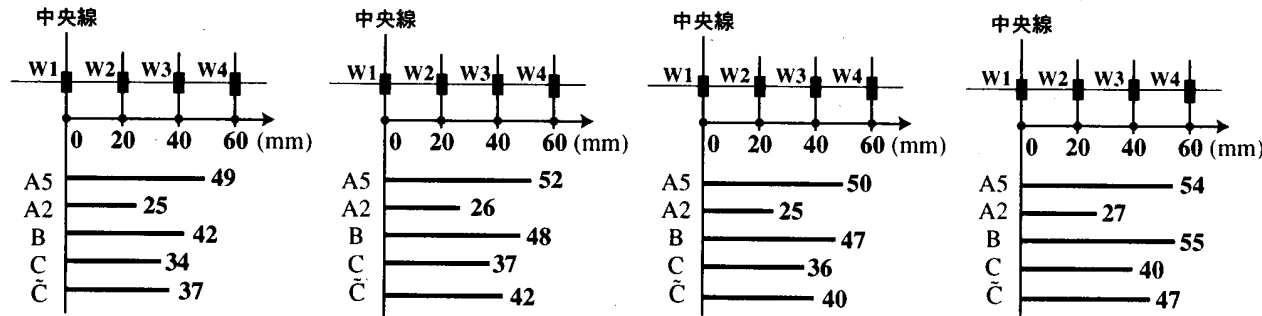

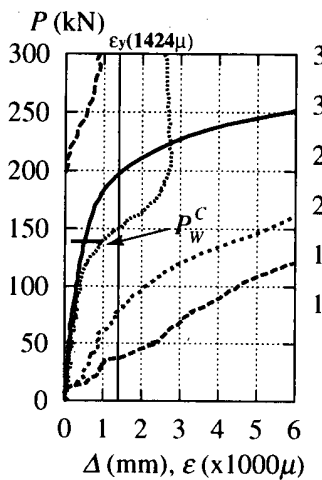

(a) 試験体 ST1

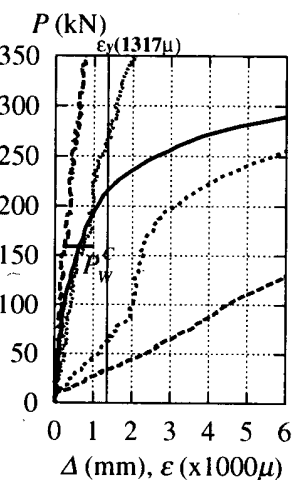

(b) 試験体 ST2

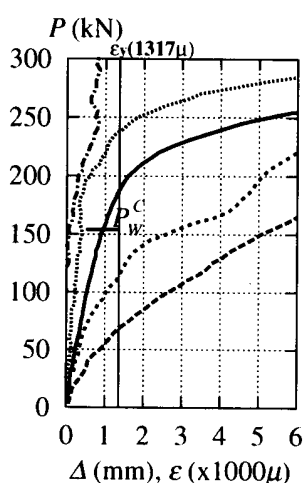

(c) 試験体 ST

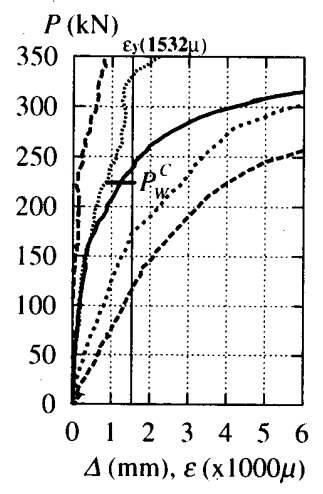

(d) 試験体 ST4

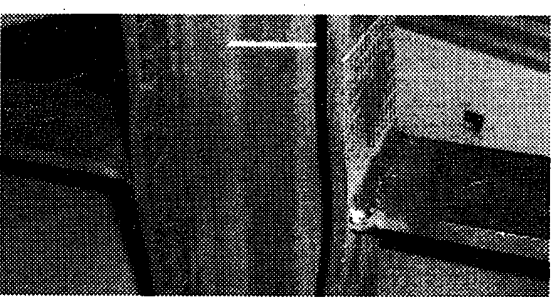

(a) 試験体 ST2 (引張載荷)

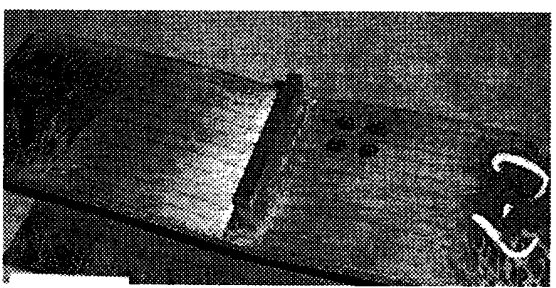

(b) 試験体 SC（圧縮載荷）

写真 1 実験後変形状態
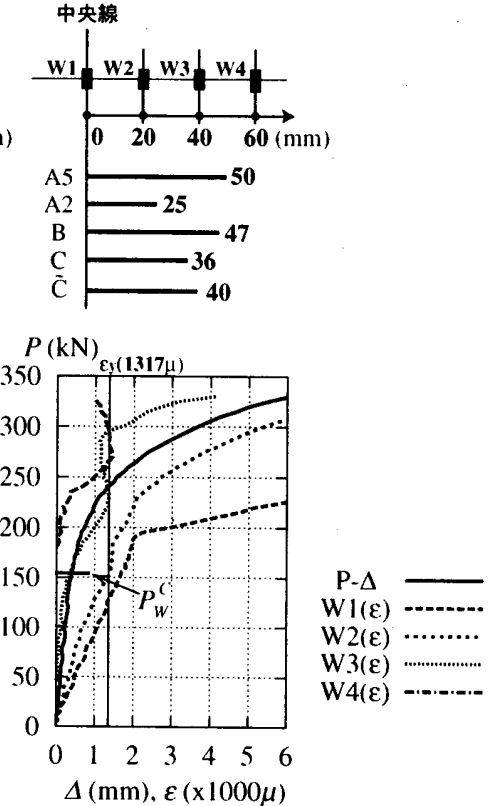

(e) 試験体 SC（圧縮歪みを正)

図 9 歪み計測位置とウェブの予想降伏範囲（片側のみ）の比較【上図】, 荷重〜変形関係および荷重〜歪み関係【下図】

\section{3 崩壊機構 Cの妥当性}

図 8 は, 実験後のフランジの面外残留変形の等高線を細い実線で, 降伏線理論により予想される降伏線位置を太い実線で描いたものであ る. 等高線は次のようにして得た. 実験後の試験体を 3 次元測定器に 固定し, a) 実験前にフランジ面に描いた $1 \mathrm{~cm}$ 間隔格子点の 3 次元座標 を測定, b) 同じフランジ面上で変形していない部分の 3 点の座標を測 定しそれら 3 点を含む平面の方程式を導出，c) a)で得た格子点の座標 とb)で得た平面との距離を計算し格子点の面外変形量を算定，d) 格子 点の面外変形量に基づき表計算ソフトを用いて等高線を描く.いずれ の試験体も等高線と予想降伏線に良好な対応が見られ, 崩壊機構 Cが 実際の破壊性状を精度良く表現しているといえる.さらに, 2.2.2節に 示した仮定 2 を無視する場合の予想降伏線を付録の図A-3に示す. 図 A-3 からも崩壊機構 Cの妥当性が分かる. 写真 1 には, 実験後の残留

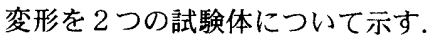

\section{4 ウェブの降伏範囲の検討}

図 1 に示したウェブ局部降伏モデル A では, 降伏範囲 $L$ が指定され
る. 他方, 図 2 の崩壊機構 B では降伏範囲が $2 \gamma+t_{h}$, 図 3 の崩壊機構 Cでは降伏範囲が $2 \alpha+n$ として降伏線理論による解析結果から得られ る. これらの予想降伏範囲と実験結果を比較する. 図 9 上図には予想 降伏範囲 (片側のみ) の大きさを棒グラフで表す. 棒グラフの長さは, それぞれA 5 は $(5 h+n) / 2, \mathrm{~A} 2$ は $(2 h+n) / 2, \mathrm{~B}$ は $(2 \gamma+n) / 2, \mathrm{C}$ は $(2 \alpha+$ $n) / 2$ の各值である. 棒グラフの上には図 5(c)に示した歪みゲージの位 置を棒グラフと対応させて示す，例えば，図 9(a)に示す試験体 ST1 で は崩壊機構 Cに対し予想される降伏範囲は中央線から $34 \mathrm{~mm}$ までの範 团であり, 歪み計測点W2 とW3の間である. よって実験でW2が塑性 域に達しW3が弾性を維持すれば, 予想降伏範囲が妥当であると判断 する. 崩壊機構Cについては, 付録に示す仮定 2 を無視する場合の予

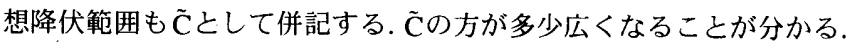

図 9 下図に荷重〜変形関係と 4 点 $\left(W_{1} 1 \sim W 4\right)$ の荷重〜歪み関保を 重ねて描く. 荷重〜変形関係曲線には $P_{W}^{C}$ のレベルを示す. 引張試験体 STI〜ST4では, 荷重が $P_{W^{\prime}}^{C}$ よりも小さい領域から, 中央部に近いW1, W2 で弾性限界 $(\varepsilon)$ ) 超えている. 他方, 圧縮試験体 $\mathrm{SC}$ では荷重が $P_{W}^{C}$ 
に達する点と W1, W2 が弾性限に達する点が近接するのが特徵的であ る. 試験体 ST1 除くと, $P_{W}^{C}$ のレベル付近では, W3, W4が弾性域に留 まることが確認できる. 図 9 上図から, A5およびBは降伏範囲を大き く予想していることが分かる. また, C̃についても試験体ST1以外では W3の位置が予想降伏範囲に多少含まれており, 本論文の実験結果から は崩壊機構 Cに対する予想降伏範囲の妥当性は確認できない.

\section{4. 結論}

H形鋼のウェブ局部降伏に対して 2 種類の崩壊機構（BおよびC）を 想定し，降伏線理論を用いて耐力評価式を導いた. フランジ幅と厚さ を考虑する点およびウェブの降伏範囲を評価する点が，一般に用いら れる耐力評価式と異なっている. 接合部実験を行い崩壊機構 Cに基づ く耐力評価結果が実験結果と良く対応することを実証した，さらに， 実験終了時のフランジ面外残留変形を検討し，崩壊機構 Cが精度良く 破壊性状を表現していることを確認した.

本論文ではウェブの局部降伏耐力に着目したが, 引張側ではフラン ジの局部曲げ, 圧縮側ではウェブの座屈など他の局部破壊形式に対す る耐力評価値についても, 実設計時には考慮する必要がある.

謝辞 本研究にあたり文部科学省科学研究費・若手研究(B) (課題番号: 14750474, 研究代表者: 田川浩) の助成を受けた. また, 日本鉄鋼連盟より実験用鋼材の支 給を受けた。ここに記して謝意を表す。

\section{参考文献}

1) 日本建築学会 : 鋼構造設計規準, 1973.

2) Load and Resistance Factor Design, 2nd Edition, Volume II, Part 10 FR Moment Connections, AISC, 1994.

3) 日本建筑学会 : 鋼構造限界状態設計指針・同解説, 1998.

4) 日本建築学会 : 鎆構造接合部設計指針, 2001.

5) Graham, J.D., et. al.: Welded interior beam-to-column connections, AISC, 1959.

6) 斎藤光, 仲威雄 : 全溶接鉄骨構造の耐力に関する研究（その 1-14）, 日本建 築学会構造系論文報告集及び日本建築学会関東支部研究発表会, 1953-1960.

7) 金谷弘, 飯盛三資, 富永尚嗣 : H 形鋼ウエプの圧壊実験, 熊本大学工学部研 究報告集, 第 12 巻, 第 1 号, pp.51-56, 1963.2

8) Packer, J.A.and Morris, L.J.: A limit state design method for the tension region of bolted beam-column connections, The Structural Engineer, Vol.55, pp446-58, 1977.10

9）森田耕次, 江波戸和正, 他 : 箱形断面柱一H形断面はり接合部のダイヤフラ 厶補強に関する研究 一接合部降伏耐力の評価一, 日本建築学会構造系論文 報告集，第388 号，pp.100-110，1988.6

10) 秋山宏, 吳相勲, 他: 無補強角形鋼管・梁接合部のモーメント一回転角関係 の一般化, 日本建築学会構造系論文集, 第 484 号, pp.131-140, 1996.6

11）书口満, 金子洋文, 他: 降伏線理論による接合部局部耐力評価 ソダ 们うム形 式のコンクリート充填角形銅管柱·梁フランジ接合部の局部引張耐力に関す る研究 (その 1), 日本建築学会構造系論文集, 第536号, pp.177-184, 2000.10

12) 佐々木聡, 寺岡勝 : $\mathrm{T}$ 形鋼で内補強されたコンクリート充填角形鋼管柱・鉄 骨梁接合部の力学的挙動, 鋼構造論文集, 第 8 巻第 29 号, pp.35-44, 2001.3

13) 吹田啓一郎, 狩野直樹, 井上一朗: 高力ボルト接合されたパネル降伏型 $\mathrm{H}$ 形 断面柱梁接合部の耐力, 日本建築学会構造系論文集, 第 559 号, pp.219-224, 2002.9

14) Wardenier, J.: Plate to I-beam connections, Welding in the World, Vol.23, No $3 / 4$, pp64-82, 1985.

15) 田川浩: 梁フランジから引張力を受ける H 形断面柱材の耐力, 日本建築学 会大会学術講演梗概集 C-1.pp 707-708, 2002.8

16）田川浩, 渡辺貴仁, Sibel Gurel : 降伏線理論によるH 形鋼ウェプの局部降伏

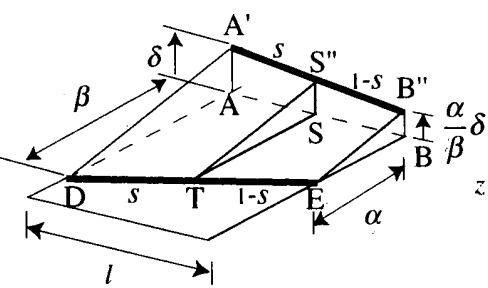

(a) ステップ 1

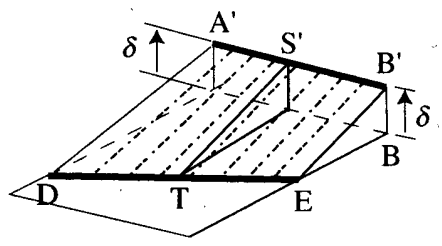

(b) ステップ2

図A-1 降伏場 b 変形状態

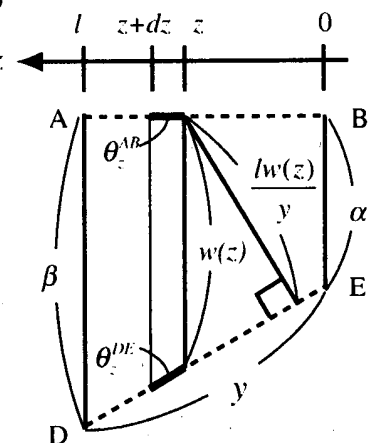

図A-2 降伏線の回転角

に対する耐力評価，日本建築学会近畿支部研究報告集、第 43 号構造系. pp.309-312, 2003.6

\section{付録 仮定の妥当性について}

2.2節において崩壊機構Cに対して降伏線理論を適用する際，2つ0 仮定を導入した，以下に，その妥当性を検討した結果を示す.

\section{【仮定 1 の検討】}

「図 3 および図 4 に示した降伏場bにおける内力仕事は小さく無視で きる」とした仮定 1 の妥当性について図A-1 を用いて考える．降伏場 bが形成される過程を 2 段階に分ける. ステップ 1 では, 辺 $\mathrm{AB}$ が直線

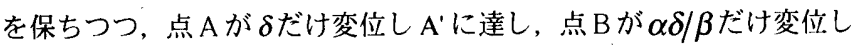
B"に達する.ここで, 線分 $\mathrm{AB}$ および線分 $\mathrm{DE}$ をそれぞれ $s: 1-s$ に内分 する点 $\mathrm{S}$ と点 $\mathrm{T}$ の間の長さの変化に着目する. 初め, $s \alpha+(1-s) \beta$ であ るST間の長さは，ステップ1では次式となる.

$$
\overline{\mathrm{S}^{\prime \prime} \mathrm{T}}=\{s \alpha+(1-s) \beta\} \sqrt{1+\left(\frac{\delta}{\beta}\right)^{2}}
$$

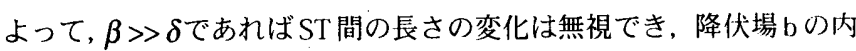
力仕事も無視できる. 式(A1)から，ステップ1では $\alpha$ の大ささは近似 精度とは関係ないことが分かる. ステップ2では, 点 $\mathrm{B}$ も点 $\mathrm{A}$ と同様 合計 $\delta$ だけ変位し B'に達する. ST 間の長さは次式となる.

$$
\overline{\mathrm{S}^{\prime} \mathrm{T}}=\{s \alpha+(1-s) \beta\} \sqrt{1+\left(\frac{\delta}{s \alpha+(1-s) \beta}\right)^{2}}
$$

よって, $\alpha>>\delta$ かつ $\beta>\delta$ であればST間の長さの変化は無視でき, 降 伏場 $\mathrm{b}$ の内力仕事も無視できる. 表 1 に示した試験体の場合には, い ずれも $\alpha$ が $20 \mathrm{~mm}$ を超えており，仮定 1 は妥当であるといえる.

\section{【仮定 2 の検討】}

仮定 2 の妥当性を検討するために，まず仮定 2 を無視する場合，即 ち降伏線 $\mathrm{AB}$ および降伏線DEの回転角が連続的に変化する場合の耐力 評価式を導出する. 図 4(b)に示した崩壊機構 Cの詳細図における四辺 形ABEDの部分を図A-2に示す. B の位置に原点があり, ABに平行で 左向きに正の $z$ 座標軸を考える. 線分 $\mathrm{AB}$ と $\mathrm{DE}$ の間の $z$ 軸に值交する 方向の距離は $z$ の関数であり図のようにw(z)で表す. $z$ の位置にある降 伏線 $\mathrm{AB}$ の回転角 $\boldsymbol{\theta}_{z}^{A B}$ および降伏線 DE の回転角 $\theta_{z}^{D E}$ もの関数であり, 
表 A-1 耐力評価値の比較

\begin{tabular}{|c|c|c|c|}
\hline 試験体 & $P_{W}^{C}(\mathrm{kN})[\xi]$ & $\tilde{P}_{w}^{C}(\mathrm{kN})\left[\tilde{\xi}^{\tilde{g}}\right]$ & $P_{w}^{C} / \tilde{P}_{w}^{C}$ \\
\hline $\mathrm{ST} 1$ (引張) & $138.6[2.15]$ & $139.5[1.70]$ & 0.9935 \\
\hline $\mathrm{ST} 2$ (引張) & $159.2[2.42]$ & $160.9[1.84]$ & 0.9894 \\
\hline $\mathrm{ST} 3$ (引張) & $153.9[2.42]$ & $155.7[1.84]$ & 0.9884 \\
\hline $\mathrm{ST} 4$ (引張) & $224.1[2.66]$ & $227.5[1.95]$ & 0.9851 \\
\hline $\mathrm{SC}$ (圧縮) & $153.9[2.42]$ & $155.7[1.84]$ & 0.9884 \\
\hline
\end{tabular}

次式で表される。

$$
\theta_{z}^{A B}=\frac{\delta}{w(z)}, \theta_{z}^{D E}=\frac{y \delta}{l w(z)} \quad \text { ここで } w(z)=\alpha+\frac{\beta-\alpha}{l} z
$$

(A3 a-c)

降伏線の単位長さあたりの全塑性モ一メントを $M_{p}$ で表すと, 降伏線 $\mathrm{AB}$ および $\mathrm{DE}$ の内力仕事（ $\tilde{E}_{A B}^{i n}$ および $\tilde{E}_{D I:}^{i n}$ ）は次式で表される.

$$
\begin{aligned}
& \tilde{E}_{A B}^{i n}=\int_{0}^{l} M_{p} \theta_{z}^{A B} d z=M_{p} \delta \frac{1}{(\beta-\alpha)} \log _{e} \frac{\beta}{\alpha} \\
& \tilde{E}_{D E}^{i n}=\int_{0}^{l} M_{p} \theta_{z}^{D E} \frac{y}{l} d z=M_{p} \delta \frac{y^{2}}{l} \frac{1}{(\beta-\alpha)} \log _{e} \frac{\beta}{\alpha}
\end{aligned}
$$

以下, 仮定 2 を無視する場合の変数は(フ)を付けて表す. 式(11c), 式(13) および式(A4a,b)を考慮すると内部仮想仕事の合計 $\tilde{E}_{C}^{i n}$ は次式のように得 られる。

$$
\tilde{E}_{C}^{i n}=4 \tilde{E}_{A B}^{i n}+4 \tilde{E}_{D E}^{i n}+4 E_{B C}^{i n}+E_{\mathrm{a}}^{i n}
$$

$\mathrm{H}$ 形鋼のウェブとフランジの降伏強さが $\sigma_{y}$ で等しい場合を考え, $M_{p}=t_{f}^{2} \sigma_{y} / 4$ で表されるとする. このとき, 仮想仕事の原理 $\tilde{E}_{C}^{i n}=E_{C}^{e x}$ から, 崩壊荷重の上界值 $\hat{\tilde{P}}_{w}^{C}$ が次式のように得られる.

$$
\hat{\tilde{P}}_{W}^{c}=t_{f}^{2} \sigma_{y}\left\{\frac{2 l \log _{e} \xi}{\xi-1}+m\right\} \frac{1}{\alpha}+\sigma_{y}\left\{\frac{t_{f}^{2}}{l}(\xi-1) \log _{e} \xi+t_{w}\right\} \alpha+n t_{w} \sigma_{y}
$$

ここで, $\beta=\xi \alpha$ を用いた. 式(A6)において, 相加平均 $\geq$ 相乗平均の関 係を考慮すると次式を得る.

$$
\hat{\tilde{P}}_{w}^{c} \geq 2 t_{f} \sigma_{y} \sqrt{\left\{\frac{2 l \log _{e} \xi}{\xi-1}+m\right\}\left\{\frac{t_{f}^{2}}{l}(\xi-1) \log _{e} \xi+t_{w}\right\}}+n t_{w} \sigma_{y} \equiv \tilde{P}_{w}^{c}
$$

等号は, 次の場合に成立する

$$
\alpha=t_{f} \sqrt{\left\{\frac{2 l \log _{e} \xi}{\xi-1}+m\right\} /\left\{\frac{t_{f}^{2}}{l}(\xi-1) \log _{e} \xi+t_{w^{\prime}}\right\}}
$$

式(A7)に示すように $\hat{\tilde{P}}_{W}^{C}$ の最小値を $\tilde{P}_{w}^{C}$ で表す. 続いて, $\tilde{P}_{w}^{C}$ の最小値を 与えるそを求めるため, 式(A7)に含まれる根号の中を次式のように関 数 $g(\xi)$ で表す.

$$
g(\xi)=\left\{\frac{2 l \log _{e} \xi}{\xi-1}+m\right\}\left\{\frac{t_{f}^{2}}{l}(\xi-1) \log _{e} \xi+t_{w^{\prime}}\right\}
$$

$g(\xi)$ を $\xi て ゙$ 微分すると次式を得る.

$$
\frac{\partial g(\xi)}{\partial \xi}=4 t_{f}^{2} \frac{\log _{e} \xi}{\xi}+\frac{m t_{f}^{2}}{l}\left(\log _{e} \xi+\frac{\xi-1}{\xi}\right)+2 l t_{w}\left\{\frac{1}{\xi(\xi-1)}-\frac{\log _{e} \xi}{(\xi-1)^{2}}\right\}
$$

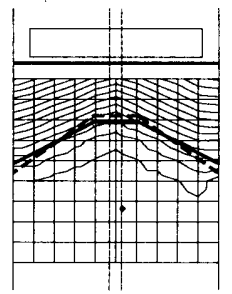

(a) 試験体 STI

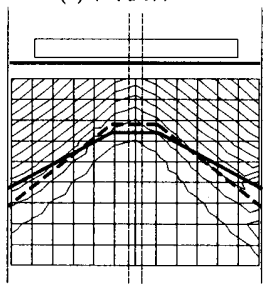

(c) 試験体 ST3

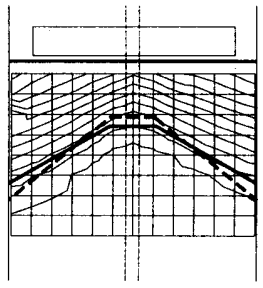

(b) 試験体 ST2

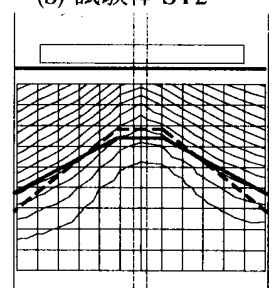

(d) 試験体 SC

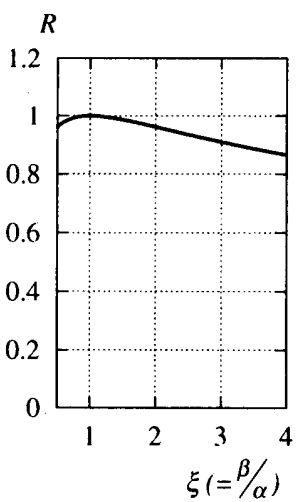

図 A-4 $R \sim \xi$ 関係
図 A-3 予想降伏線の比較

（実線：仮定 2 を無視，破線：仮定 2 を考慮）

ここで, $\partial g(\xi) / \partial \xi=0$ をちる $\xi$ (以下, $\tilde{\xi} て ゙$ 表す) を陽に求めるのは困 難であり, 数值計算により求める必要がある. これが, 本論文で仮定

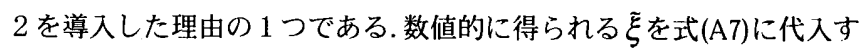
ると, 耐力評価値 $\tilde{P}_{w}^{C}$ が得られる. また, $\tilde{\xi}$ を式(A8)に代入して得られる $\alpha$ おび $\beta(=\tilde{\xi} \alpha)$ から，降伏線が現れる位置を予想できる.

表A-1に, 本論文で用いた試験体について, 仮定 2 を考慮する場合 の耐力評価値 $P_{W}^{C}$ と仮定 2 を無視する場合の耐力評価值 $\tilde{P}_{W}^{C}$, およびそ れらの比 $\left(P_{w}^{C} / \tilde{P}_{w}^{C}\right)$ を示す. 耐力評価值には, それぞれの值を与え

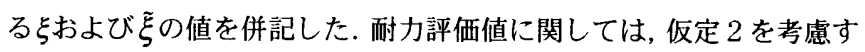
る方が僅かに小さく評価しているが, 両者の差は小さく仮定 2 は妥当 であるといえる. 一方, 耐力評価值を与える $\xi(=\beta / \alpha)$ の值については 比較的大きな差がある. 図A 3 には, 面外残留変形を示す等高線と重 ねて, 仮定 2 を無視する場合の予想降伏線を太い実線で, 仮定 2 を考 慮する場合の予想降伏線（図 8 に示した）を破線で示す. 仮定 2 を無 視する場合（実線）の方が $\xi$ の值が小さく $\alpha$ と $\beta$ の長さの差が小さく なっているが, 仮定 2 を考慮する場合（破線）と比べると $\alpha$ 大゙きく, $\beta$ 斾さくなることが分かる.

仮定 2 を考慮すると無視する場合よりも耐力が小さく評価される, 即ち安全側に評価されることの一般性を検討するために, 降伏線にお ける内力仕事を比較する. 式(11a,b)および式(A4a,b)を考慮すると, 降. 伏線 $\mathrm{AB}$ における内力仕事について, 仮定 2 を考慮する場合の無視す る場合に対する比 $R$ は, 降伏線 DEにおける内力仕事のそれと等しく, 次式で表される.

$$
R=\frac{E_{A B}^{i n}}{\tilde{E}_{A B}^{i n}}=\frac{E_{D L}^{i n}}{\tilde{E}_{D E}^{i n}}=\frac{2}{\log _{e} \xi} \frac{(\xi-1)}{(\xi+1)}
$$

$R$ Rは部材の寸法等は含まれず $\xi$ だけの関数である. 式(A11)のグラフ を図A-4に示す. 表A-1 から分かるように, 本論文で用いた試験体で は $\xi$ の值が概ね $1.7 \sim 2.7$ であり, 対応する $R$ の值は $0.9 \sim 1.0$ の範囲内 にある. 即ち, 仮定 2 を考慮する場合の方が, 降伏線 $\mathrm{AB}$ およびDEに おける内力仕事が小さく評価される.これが, 仮定 2 を考虑した場合 に耐力が安全側に評価される原因であると考えられる.

(2003年 6 月 4 日原稿受理, 2003 年 8 月 6 日採用決定) 